\title{
Using Journal Entries and Assigned Writing to Promote Students' Critical Thinking
}

\author{
Syaadiah Arifin ${ }^{1}$, Hamzah Fuadi Ilyas ${ }^{2}$, Maula Sukmawidjaya ${ }^{3}$
}

Sekolah Pasca Sarjana Universitas Muhammadiyah Prof. Dr. Hamka ${ }^{1 \& 2}$, Indonesia Fakultas Industri Universitas Trisakti ${ }^{3}$, Indonesia

Correspondence: Syaadiah Arifin, Universitas Muhammadiyah Prof. Dr. Hamka. Indonesia. e-mail: syaadiah.arifin@uhamka.ac.id

Submitted: April 03, 2020

Revised: April 20, 2020

Accepted: April 24, 2020

DOI: $10.29408 /$ veles.v4i1.2020

URL: http://dx.doi.org/10.29408/veles.v4i1.2020

\begin{abstract}
This research aims to determine the ability of journal entries and assigned writing to foster students' critical thinking. A total of six components, namely, interpretation, analysis, evaluation, inference, explanation, and self-regulation, were used to carry out this study. Data were obtained from a total of twelve (12) students majoring in English Education from one of the universities in Jakarta by using semi-structured interview and text-analysis. Journal entries submitted by the students as a course prerequisite were evaluated and analyzed by two raters. The result showed that many students lack important critical thinking skills required for a successful study, and to acquire good employment after graduating from college. In addition, the use of journal entries and assigned writing has the ability to promote the critical thinking level to varying degrees.
\end{abstract}

Keywords: Critical thinking, journal entries, assigned writing,

\section{Introduction}

Critical thinking is important in education, and its improvement needs to be considered as one of the primary objectives for teachers at all stages (Gelder, 2005; Guiller, Durndell, \& Ross, 2008). According to Norris (1985), critical thinking skill is not an educational option, therefore students need to be taught on how to develop their skills as it tends to support indepth learning. This is important because students are encouraged to question any information they receive. Based on the research by Quitadamo \& Kurtz (1993), critical thinking is essential in education. For example, students that exhibit such skills in any discipline tend to be more successful in their studies. According to El Soufi \& See (2019), students that possess such skills to have a vibrant future career and are readily employable.

The educational authority in Indonesia has integrated critical thinking as one of its goals as written in the Regulation in Indonesia Number 17 Year 2010. Nowadays, improving students' abilities through education is the primary objective of the academic sector (Ningsih, 2016). However, some scholars have reported that several Indonesian students possess inadequate thinking skills, due to lack of practice and training (Indah, 2017; Velayati, Muslem, 
Fitriani, \& Samad, 2017). In higher education, some subjects are geared towards this skill; therefore, students need to express their opinion supported by facts, data and experts' opinion.

There are several ways to improve students' critical thinking skills such as journal writing (Cisero, 2006; Nabhan, 2016; Reinertsen \& Wells, 1993; Sinaga \& Feranie, 2017; Stanton \& Stanton, 2017; Walker, 2006). However, there has been insufficient empirical records and literature on journal writing's ability to promote this skill in the Indonesian context, particularly in English Higher Education.

Therefore, this study aims to determine journal entries and assigned writing ability to promote students' critical thinking. Despite the fact that journal writing offers students the opportunities to be critical, they also need to obtain ample feedback from the teachers or lecturers, and this, however, leads to their enhancement (Hogsette \& Glazer, 2012). It is, therefore, concluded that teachers or lecturers play a significant role to augment students' critical thinking skills.

Apart from the significance of critical thinking skills in education, the definition of critical thinking tends to appear intricate because it lacks lucidity and with no test designed to assess this skill. Moore (2013) stated that it is the most indefinable concept. One of the examples of how elusive the term critical thinking stated by (Hughes, 2014) is when there was an online webinar for a hundred English teachers, the lecturer started by asking the participants to share their ideas on the term critical thinking. Surprisingly, there were tens of conceptions and definitions of the term Critical thinking. Furthermore, various definitions have been defined in accordance with this term. Brookfield (2012) defined critical thinking as an action to verify assumptions by viewing things from different perspectives. It was stated that it commences from querying whether assumptions that influence our actions and thoughts are valid. Additionally, different perspectives are taken into account before carrying out an action. Therefore, the individual is informed in the facts that tend to support such action that needs to be taken seriously.

Brookfield's definition is different from Ennis' (1989) definition, which concentrates on "deciding what to believe or do" (p.4). In the meantime, Moore \& Parker (2009) reported that it is the act by which a person's motive decides whether a claim is true (p.3). According to Stanton \& Stanton (2017), this skill is the application of cognitive approaches to enhance the possibility of a positive result. These studies have shown that researchers have different perspectives on critical thinking.

In this research, the definition is adopted from the conceptions of Facione (2015) with its fundamental skills conceptualized into cognitive and disposition skills. Experts reported that cognitive skills are the basis of critical thinking, and it involves six abilities, namely interpretation, analysis, evaluation, inference, explanation, and self-regulation. Interpretation is the capability of comprehending information that conveys the meaning or the importance of various experiences, circumstances, data, judgments, conventions, beliefs, rules, procedures, or criteria(Facione, 2015). Meanwhile, analysis is the capability of classifying the envisioned and real inferential relationship between statements, queries, notions, descriptions, or other forms of representation (Facione, 2015). Subsequently, the inference is the ability to identify, decide, draw sensible conclusions based on resilient reason, deduce assumptions and hypotheses, as well as to acquire information or consequences in accordance with this decision (Facione, 
2015). According to the experts, an explanation is defined as the ability to convincingly and clearly communicate. It involves sub-skills which depicts methods, results, justifies procedures, proposes and one's factual and theoretical explanations, and provides reasonable suggestions as well as arguments in the context of discovering the best comprehension possible (Facione, 2015). Self-regulation is defined as ones' ability to monitor their thinking and cognitive activities. It consists of two sub-skills, namely self-examination and self-correction (Facione, 2015). The conception of (Facione, 2015) is suitable for the current research. Students had to write their journal entry with the assigned writing based on the abilities, such as to interpret the issue, and data, to analyze the primary purpose, to evaluate the main point of views, to infer or to draw a sensible conclusion, to explain primary results and procedures, and to regulate and monitor individual's cognitive activities.

A journal is a task that needs authors to reflect on an article and to record their thoughts (Moon, 2006). Journal writing has different terminologies, namely dialogue, entries, learning, writing, and reflective. However, in this study, the terms Journal writing and journal entry were used interchangeably. Journal writing has different benefits following the goals of the teachers and students. Various studies have provided strong evidence that journal writing is a commonly-used activity to cultivate critical thinking (Estrada \& Mariam Rahman, 2014; Hogsette \& Glazer, 2012; Stanton \& Stanton, 2017). Moreover, it also promotes creativity and critical reflection(Arter, Wallace, \& Shaffer, 2016; Loo, 2001), analytically evaluates perceptions and theories (Bahmani, 2016), and encourages students to be active learners (Walker, 2006). Other benefits are, it increases reflective skills that enhance self-confidence (Lyons, 1999), prepares students for future jobs (Lang \& McNaught, 2013) and builds a relationship between course material and experiences (Connor-Greene, 2000). As a medium for communicating and expressing thoughts, Klein(2004), reported that it offers great contributions to the development of critical thinking as the attainment in the manifestation of thought.

Stanton \& Stanton (2017) in research carried out in one of the universities in The USA, stated that Journal writing is applied in any discipline. They carried out an investigation on a teaching innovation to develop students' skills and learn the concepts taught in the retailing class. Those that developed learning journals performed better. Another study involving 17 mass communication students in Egypt was conducted by Shaarawy (2014a) on the effectiveness of journal writing to develop students' thinking abilities. Only the experimental group was assigned to write a weekly journal, however, both groups were taught by the same instructor. The result showed that the journal writing assignments provided to the experiment group contributed significantly to the development of their cognitive skills.

Wicaksono (2006) conducted research using $245^{\text {th }}$ grade students in Ngenep-Surabaya studying the civic subject. The students were asked to write a reflective journal concerning their perspective from the beginning till the end of the learning process. The findings showed an enhancement in their thinking phases, such as focus, reasoning, inference, situation, and clarity. Besides demonstrating the positive contribution of journal writing to enhance students' abilities, this research also reported critical thinking skills need to be developed at a young age.

Bouanani (2015) conducted a research in Morocco aimed to foster students' skills using the reflective journal. The participant were experts in business, marketing and finance, with a total of thirty Moroccans' reflective writing production evaluated and progressed extensively. The 
studies above showed the effectiveness of journal writing in boosting students' skills. Similar researches that utilized journal writing to develop students' critical thinking abilities were also conducted by some Asian researchers (Abdullah \& Sharadgah, 2014; Arslan \& Yildiz, 2012; Estrada \& Mariam Rahman, 2014; Khatib, Marefat, \& Ahmadi, 2012; Nabhan, 2016).

The use of journaling to measure college students' knowledge is a common practice in Western and Non-Western countries. However, in the Indonesian context, there is a scarcity of literature on the use of journal writing to promote and nurture critical thinking of Higher English Education students. Most of the researches conducted in Indonesia involved undergraduates from different fields such physic education and study programs (Sinaga \& Feranie, 2017), English Education(Velayati et al., 2017), and Senior High School Students in science classes (Nuri, Sajidan, Oetomo, Prasetyanti, \& Parmin, 2019).

Bloom's taxonomy has been widely applied to measure an individual's critical thinking skills (Arter et al., 2016; Ballantyne \& Packer, 1995; Fuller, 1997; Nentl \& Zietlow, 2008; Shaarawy, 2014b; Threlfall, 2014). However, this study utilized the taxonomy created by Facione \& Facione (1994) due to its suitability for the purpose of this research which is to determine the level of students' critical thinking through journal writing in accordance with assigned topics.

\section{Method}

\subsection{Participants}

The participants of this study were twelve (12) graduates in English Education, and they all have a background in the course. Also, some of the participants were lecturers, while others were secondary school teachers with over three (3) years' experience. In this study, the researcher purposely selected the first semester students of the academic year 2019/2020 as they had to be trained on how to think critically from the very beginning. All of the students had gone through some entrance tests such as the Toefl test. In this test, they had to meet the required Toelf score (550). The other tests were Academic Writing and Academic Potential Tests. Therefore, if they could get accepted in the graduate program, it was assumed that they had sufficient knowledge of English; therefore, they were eligible to join the research.

\subsection{Data Collection}

\subsubsection{Instruments}

This is a qualitative research with data obtained from Forty-eight (48) articles submitted by twelve graduates majoring in English Education. The data were analyzed and evaluated by two raters using the taxonomy developed by Facione \& Facione (1994) based on interpretation, analysis, evaluation, inference, explanation, and self- regulation (Facione, 2015). A semistructured interview was applied to triangulate the data obtained from the tasks assigned to the students, and it was also intended to discover their opinion on the journal entry and assigned writing

\subsubsection{Techniques for Collecting Data}

Approaches and methods in TESOL is one of the core subjects conducted in the first semester in the university where the research was conducted. The course consists of a total of sixteen meetings, with two conducted during the mid-term and final tests. Subsequently, seven meetings were conducted before the mid-term test, while the rest were after the test. All 
the participants are either English teachers or lecturers; therefore they are familiar with some of the topics.

However, since all participants were in the master's program, all topics were comprehensive to them compared to their undergraduate days. The importance of reading textbooks and journals extensively was emphasized in accordance with the broad nature of the subjects. The students were advised to become avid readers and active in the classroom. The class integrated lectures, presentations, textbook readings and discussion with the ability to help students understand certain information concerning the subject.

Table1: The list of the topics that students should write

\begin{tabular}{ll}
\hline No & Topics \\
\hline 1 & Approaches and Methods in Teaching English \\
2 & Teaching English for Young Learners \\
3 & Post-Methods Pedagogy \\
4 & Learner Autonomy \\
\hline
\end{tabular}

In the first meeting, the course materials and requirements needed to write journal entries regularly were analyzed. All students were also assigned to read the first topic, as well as the approaches and methods in teaching English. Two students were asked to present the same topic taken from international journals and textbooks.

In the second meeting, the subjects participated in discussions conducted after the lecturer presented the first topic. Another discussion was carried out after a pair of students presented a topic from the journal which was related to the assigned task. Before the class was over, the lecturer introduced another topic entitled "Teaching English for Young Learners".

In the third meeting, students had to submit their first journal entries based on their reactions to traditional approaches and methods in teaching English in the EFL context. Students also had to write a-500-word journal entry in which stating why they find the topic exciting. Furthermore, they had to explain whether they agreed or disagreed with the author's perspective with data, evidences and examples to support their arguments, which was concluded with a sensible suggestion. In this meeting, the lecturer presented the topic which was followed by class discussion. Subsequent meetings were in accordance with the steps of the previous ones.

The researcher who was also a lecturer of this subject and another rater spent some time reading and marking all the journal entries written by the students on a weekly basis. The lecturer discussed the students' journals in the class and provided feedback before the next assignment. The students were asked to apply their critical thinking skills when writing entries.

\subsection{Data Analysis}

Students' journal entries were analyzed and evaluated by two raters using the Holistic Critical Thinking rubric created by Facione \& Facione (1994). The interviews with the students were coded and transcribed. A total of 10 questions were utilized, based on the 
obstacles they encountered during the process of journal writing and their opinion on the tasks provided.

Table 2: Holistic critical thinking scoring rubric (HCTTR) by Facione \& Facione (1994)

\begin{tabular}{|c|c|}
\hline Score & Criteria \\
\hline 4 (strong) & $\begin{array}{l}\text { - Accurately interpreting data, statements and questions on the given } \\
\text { topic } \\
\text { - Identifying the main point of views (reasons and claims), the pros } \\
\text { and cons } \\
\text { - Thoughtfully analyzing and evaluating the main alternative points } \\
\text { of view } \\
\text { - Drawing acceptable and thoughtful conclusions } \\
\text { - Justifying the main results and procedures, clarifying statements } \\
\text { and reasons. } \\
\text { - Fair-mindedly follows where evidence and reasons lead. }\end{array}$ \\
\hline 3 (acceptable) & $\begin{array}{l}\text { - Accurately interpreting data, statements and questions on the } \\
\text { given topic } \\
\text { - Identifying the main point of views (reasons and claims), the pros } \\
\text { and cons } \\
\text { - Offering analyses and evaluations towards the main alternative } \\
\text { points of view } \\
\text { - Presenting students' perspective and position based on the topic } \\
\text { - Drawing an acceptable, thoughtful conclusion } \\
\text { - Justifying the main results and procedures, clarifying statements } \\
\text { and reasons. } \\
\text { - Fair-mindedly follows where evidence and reasons lead. }\end{array}$ \\
\hline 2 (unacceptable) & $\begin{array}{l}\text { - } \text { Misinterpreting data, statements, questions, etc. } \\
\text { - } \text { Failing to classify strong, related counter-arguments } \\
\text { - } \text { Ignoring or superficially evaluating clear alternative points of view } \\
\text { - } \text { Drawing unacceptable or misleading conclusions } \\
\text { - Justifying few results or procedures, that infrequently explains } \\
\text { reasons } \\
\text { - } \text { Regardless of the evidence or reasons, maintaining or defending } \\
\text { views based on personal interest or preconceptions }\end{array}$ \\
\hline 1 (weak) & $\begin{array}{l}\text { - Offering misinterpretations of data, statements, questions, } \\
\text { information, or others' perspectives } \\
\text { - Failing to identify or hastily dismissing strong, relevant counter- } \\
\text { arguments } \\
\text { - Ignoring or superficially evaluating obvious alternative points of } \\
\text { view } \\
\text { - Arguing using misleading and unrelated reasons, and unnecessary } \\
\text { claims } \\
\text { - No justification of the results or procedures, neither explanation of } \\
\text { the reasons } \\
\text { - regardless of the data or reasons, maintaining or defending views } \\
\text { based on personal interest or preconceptions } \\
\text { - Showing close-mindedness or hostility to reason }\end{array}$ \\
\hline
\end{tabular}




\section{Findings and Discussion}

The six components of critical thinking skills in students were analyzed and evaluated by two raters, namely the researcher and another lecturer who teaches Academic writing. Table 3 shows the students' scores level in each assigned topic using Facione \& Facione's (1994) rubric.

Table 3. The level of each student' critical skills in writing the assigned topics

\begin{tabular}{lllll}
\hline Student & Assignment 1 & Assignment 2 & Assignment 3 & Assignment 4 \\
\hline S1 & 3 & 3 & 4 & 4 \\
S2 & 2 & 2 & 3 & 3 \\
S3 & 3 & 4 & 4 & 4 \\
S4 & 2 & 3 & 3 & 3 \\
S5 & 2 & 3 & 3 & 3 \\
S6 & 2 & 3 & 3 & 3 \\
S7 & 2 & 2 & 3 & 3 \\
S8 & 3 & 3 & 4 & 4 \\
S9 & 2 & 2 & 3 & 3 \\
S10 & 2 & 3 & 3 & 3 \\
S11 & 3 & 3 & 3 & 4 \\
S12 & 2 & 2 & 3 & 3 \\
\hline
\end{tabular}

\subsection{Critical Thinking Skills/ Components}

\subsubsection{Interpretation}

This is the ability to comprehend information, and students' ability to interpret data, statements and questions on the given topic. During the first assignment, many students only wrote a summary of what they had initially read without expressing their opinion, which was obviously not the purpose of writing the entry. Here are some excerpts taken from the interview,

S2: "I am familiar with the term critical thinking; however, I have not practiced it in writing. During my undergraduate program, lecturers didn't emphasize its importance. We were only asked to have classroom presentations."

S4: "it was quite challenging when writing a journal entry for the first time. However, since it is a compulsory task, it was expected that the students to read and write extensively."

\subsubsection{Analysis}

Analysis is the ability to identify the of the main purpose arguments stated by the writer when the article or textbook is read. It also embraces investigating ideas, perceiving and examining arguments, comparing, contrasting and differentiating. During the course of writing the first assignment, many students expressed their personal opinion, although it was not supported by facts, data and the experts' findings. They argued on a topic like it was their personal discovery, and no citations were made. However, students in S1, S3, S8 and S11 were able to offer acceptable arguments during the first assignment. 


\subsubsection{Evaluation}

It is the ability to assess the credibility of statements, claims concerning one's perception, opinion and belief. The sub-skills evaluated are the hardest because students need to compare their opinion with the expert when writing. Many students had a problem when explaining to what extent they agreed or disagreed with the author's perspectives.

\subsubsection{Inference}

This is the capability to identify and to draw a sensible conclusion. Most of the students wrote their conclusion; however, some were only able to summarize what they had written. In the actual sense, a good conclusion needs to emphasize the main ideas which determine their ability to agreed or disagreed with something in response to the question.

\subsubsection{Explanation}

This is the capability of informing the process of thinking or communicating the conclusion to others. This skill includes the activities of justifying primary results and procedures as well as clarifying statements and reasons. Subsequently, some students didn't explain their reasons for finding the topic interesting. In their writing, they didn't provide strong reasons behind their agreement or disagreement with the authors' point of view. They just simply agreed or disagreed without any explanations.

\subsubsection{Self-regulation}

Self-regulation is the ability to regulate one's thinking and either reforms its reasoning and results. It monitors an individual's cognitive activities such as analyzing and evaluating one's inferential judgment. The students carried out their first assignment, with little evaluation and analysis on their writings.

All the situations stated occurred when the students wrote their first task. After writing their first journal entry, they were offered ample feedback by the lecturer. Many examples were also picked from the student's writings which met the criteria of a fairly good journal entry, and it was discussed in the class before the second assignment. The lecturer also emphasized on the importance of studying the articles relating to the literature read in the course. They had to state the primary focus or purpose of the articles and summarize the main point or argument which they found interesting. Moreover, students had to be adequately prepared in order to establish and defend their position. They often propose statements such as "this is a self-opinion," "these are personal perspectives," or "nobody needs to question how I feel." Nonetheless, critical thinking involves the ability of students to move beyond their personal opinions and maintain arguments with clear logic and precise descriptions of dependable evidence as well as pertinent experience.

As stated in Table 3, students developed varying degrees of critical thinking skills. Only a few students in S1, S3 and S8 were able to improve their skills quite significant. In addition, two students were able to interpret, analyze, evaluate, offer an appropriate explanation on the given topic and provided a practical conclusion. Some of the interview excerpts are stated below.

S3: "the writing of journal entries encouraged students to think critically, analyze and take decision. It is related to method, technique and conclusion." 
S8: "journal entry offers opportunities for critically thinking by studying linguists' views, observing students' condition and reading books from different sources."

Based on the data obtained, it was concluded that students tend to properly develop critical thinking skills when they are familiar with the topics, and this is also impressive. When writing the $3^{\text {rd }}$ assignment, which is titled "Post Method Pedagogy," the students found the topic intriguing due to the fact that similar method was applied when teaching their students and this deeply agrees with Kumaravadivelu's (2001) theory despite some drawbacks that were encountered in this method. Furthermore, students were also interested in the $4^{\text {th }}$ assignment on learner autonomy. The implementation of learner autonomy encountered some challenges regarding students' and teachers' readiness (Mardjuki, 2018). However, presently teachers try to employ learner autonomy through various activities, such as Blended Learning. Some participants of this research already applied this technique to encourage their students to be autonomous learners.

\section{Conclusion}

The primary purpose of this research is to examine the ability of journal entries aids in promoting students' critical thinking. The result of this study showed that although journal writing helped students improve these skills, there was a discrepancy in their performance during the four sessions. Students had varying degrees of critical thinking skills however, only a few were able to achieve stages three (3) and four (4). The possible explanation for this is lack of experience, practice and training involved in journal writing by the majority of the students with the skills developed through extensive instructions. Critical thinking is not only limited to smart students, with additional varying levels achieved. However, teachers are responsible for providing opportunities for the development of these abilities by evaluating students' at a young age. Therefore, it is worthy of teachers to invest in journal entries which is an efficient and practical technique that tends to assist students in developing their skills. Moreover, promoting critical thinking abilities is beneficial, particularly for higher education students because they are indispensable capabilities. These students tend to apply these skills when writing their thesis in which they have to defend their point of view, argue over certain data, evidence and experts' opinion.

\section{References}

Abdullah, T., \& Sharadgah, A. (2014). Developing Critical Thinking Skills through Writing in an Internet-Based Environment. 4(1), 169-178.

Arslan, R. S., \& Yildiz, N. (2012). Enhancing critical thinking at the tertiary level through a literature-based critical thinking program. Ç. U. Sosyal Bilimler Enstitüsü Dergisi, 21(2), 19-36. Retrieved from file:///C:/Users/user/Downloads/ArslanYldzukurovamakle.pdf

Arter, M. L., Wallace, L. N., \& Shaffer, T. L. (2016). The Use of Reflective Journals to Stimulate Critical Thinking in the Academic Internship. Journal of Criminal Justice Education. https://doi.org/10.1080/10511253.2015.1109132

Bahmani, S. (2016). Improved Critical Thinking in Students Using Current Events Journaling. International Journal of Sociology and Social Policy, 36(3/4). https://doi.org/10.1108/IJSSP-04-2015-0038 
Ballantyne, R., \& Packer, J. (1995). The role of student journals in facilitating reflection at doctoral level. Studies in Continuing Education, 17(1-2), 29-45. https://doi.org/10.1080/0158037950170104

Bouanani, N. (2015). Enhancing Critical Thinking Skills through Reflective Writing Intervention among Business College Students. IOSR Journal of Research \& Method in Education (IOSR-JRME), 5(1), 50-55. https://doi.org/10.9790/7388-05135055

Brookfield, S. (2012). Teaching for Critical Thinkin. San Fransisco: JOSSEY-BASS A Wiley Imprint.

Cisero, C. A. (2006). Does Reflective Journal Writing Improve Course Performance? College Teaching, 54(2), 231-236. https://doi.org/10.3200/CTCH.54.2.231-236

Connor-Greene, P. A. (2000). Making Connections: Evaluating the Effectiveness of Journal Writing in Enhancing Student Learning. Teaching of Psychology, 27(1), 44-46. https://doi.org/10.1207/S15328023TOP2701_10

El Soufi, N., \& See, B. H. (2019). Does explicit teaching of critical thinking improve critical thinking skills of English language learners in higher education? A critical review of causal evidence. Studies in Educational Evaluation, 60(August 2018), 140-162. https://doi.org/10.1016/j.stueduc.2018.12.006

Ennis, R. H. (1989). Critical Thinking and Subject Specificity: Clarification and Needed Research. Educational Researcher, 18(3), 4-10. https://doi.org/10.3102/0013189X018003004

Estrada, F. F., \& Mariam Rahman, A. (2014). Reflective journal writing as an approach to enhancing students' learning experience. Brunei Darussalam Journal of Technology and Commerce.

Facione, P., \& Facione, N. (1994). Holistic critical thinking scoring rubric. Retrieved July, 19, 2007. Retrieved from http://aacusecure.nisgroup.com/meetings/pdfs/criticalthinkingrubric.PDF

Fuller, D. (1997). Critical thinking in undergraduate athletic training education. Journal of Athletic Training, 32(3), 242-247.

Gelder, T. Van. (2005). Teaching Critical Thinking: Some Lessons From Cognitive Science. College Teaching, 53(1), 41-48. https://doi.org/10.1063/1.3047631

Guiller, J., Durndell, A., \& Ross, A. (2008). Peer interaction and critical thinking: Face-to-face or online discussion? Learning and Instruction, 18(2), 187-200. https://doi.org/10.1016/j.learninstruc.2007.03.001

Hogsette, D., \& Glazer, F. (2012). Tips From Innovative Teaching at UWF : Develop Critical Thinking Skills through Journal Writing. (7), 7-8. Retrieved from https://www.academia.edu/3708624/Develop_Critical_Thinking_Skills_through_Journal_ Writing

Hughes, J. (2014). Critical Thinking in the Classroom. In ELI (pp. 1-27). Retrieved from https://cdn.ettoi.pl/pdf/resources/Critical_ThinkingENG.pdf

Indah, R. N. (2017). Critical Thinking, Writing Performance and Topic Familiarity of Indonesian EFL Learners. Journal of Language Teaching and Research, 8(2), 229. https://doi.org/10.17507/jltr.0802.04

Khatib, M., Marefat, F., \& Ahmadi, M. (2012). Enhancing critical thinking abilities in EFL 
classrooms: Through written and audiotaped dialogue journals. 7(1), 33-45. https://doi.org/10.5829/idosi.hssj.2012.7.1.1104

Klein, P. D. (2004). Constructing scientific explanations through writing. Instructional Science, 32(3), 191-231. https://doi.org/10.1023/B:TRUC.0000024189.74263.bd

Kumaravadivelu, B. (2001). Toward a Postmethod Pedagogy. TESOL Quarterly, 35(4), 537. https://doi.org/10.2307/3588427

Lang, R., \& McNaught, K. (2013). Reflective practice in a capstone business internship subject. Journal of International Education in Business, 6(1), 7-21. https://doi.org/10.1108/18363261311314926

Loo, R. (2001). Journaling: A Learning Tool for Project Management Training and TeamBuilding. 33(4), 61-66. https://doi.org/10.1177/875697280203300407

Lyons, J. (1999). Reflective education for professional practice: Discovering knowledge from experience. Nurse Education Today, 19(1), 29-34. https://doi.org/10.1054/nedt.1999.0607

Mardjuki, M. S. (2018). Learner Autonomy: Gender-Based Perception Among EFL Indonesian Students. Indonesian Journal of EFL and Linguistics, 3(1), 1. https://doi.org/10.21462/ijefll.v3i1.46

Moon, J. A. (2006). Learning Journals A Handbook for Reflective Practice. In Routledge (2nd Editio, Vol. 52). https://doi.org/10.1177/0308518X17752682

Moore, B., \& Parker, R. (2009). Critical Thinking (Ninth Edit). https://doi.org/10.1111/j.10958339.1867.tb00425a.x

Moore, T. (2013). Critical thinking: Seven definitions in search of a concept. Studies in Higher Education, 38(4), 506-522. https://doi.org/10.1080/03075079.2011.586995

Nabhan, S. (2016). Students' journal writing: Promoting reflective learning on students' perception and comprehension towards students' self-awareness and critical thinking development in english as foreign language classroom. Proceeding of the 7th International Conference on Educational Technology of Adi Buana (ICETA-7), (March), 449-456.

Nentl, N., \& Zietlow, R. (2008). Using Bloom's Taxonomy to teach critical thinking skills to business students. College and Undergraduate Libraries. https://doi.org/10.1080/10691310802177135

Ningsih, H. K. (2016). Multilingual re-instantiation: Genre pedagogy in Indonesian classrooms (PhD Thesis). (February). Retrieved from http://www.isfla.org/Systemics/Print/Theses/HKartika-Ningsih_thesis.pdf

Norris, S. P. (1985). The Choice of Standard Conditions in Defining Critical Thinking Competence. Educational Theory, 35(1), 97-107. https://doi.org/10.1111/j.17415446.1985.00097.x

Nuri, A. R. U., Sajidan, S., Oetomo, D., Prasetyanti, N. M., \& Parmin, P. (2019). Improving Indonesian Senior High School Students' Critical Thinking Skill through Science Integrated Learning (SIL) Model. Tadris: Jurnal Keguruan Dan Ilmu Tarbiyah, 4(2), 145-158. https://doi.org/10.24042/tadris.v4i2.3144

Quitadamo, I. J., \& Kurtz, M. J. (1993). Curriculum \& Leadership Journal _ Skills for the 21st Century_ teaching higher-order thinking. CBE - Life Sciences Education, 6, 1-15. https://doi.org/10.1187/cbe.06

Reinertsen, P. S., \& Wells, M. C. (1993). Dialogue Journals and Critical Thinking. Teaching 
Sociology, 21(2), 182. https://doi.org/10.2307/1318641

Shaarawy, H. Y. (2014a). The Effect of Journal Writing on Students' Cognitive Critical Thinking Skills A Quasi-Experiment Research on an EFL Undergraduate Classroom in Egypt. International Journal of Higher Education. https://doi.org/10.5430/ijhe.v3n4p120

Shaarawy, H. Y. (2014b). The Effect of Journal Writing on Students' Cognitive Critical Thinking Skills A Quasi-Experiment Research on an EFL Undergraduate Classroom in Egypt. International Journal of Higher Education, 3(4), 120-128. https://doi.org/10.5430/ijhe.v3n4p120

Sinaga, P., \& Feranie, S. (2017). Enhancing critical thinking skills and writing skills through the variation in non-traditional writing task. International Journal of Instruction, 10(2), 69-84. https://doi.org/10.12973/iji.2017.1025a

Stanton, A. D., \& Stanton, W. W. (2017). Using journaling to enhance learning and critical thinking in a retailing course. Journal for Advancement of Marketing Education.

Threlfall, S. J. (2014). E-journals: towards critical and independent reflective practice for students in higher education. Reflective Practice, 15(3), 317-332. https://doi.org/10.1080/14623943.2014.900012

Velayati, N., Muslem, A., Fitriani, S. S., \& Samad, I. A. (2017). An Exploration of Students' Difficulties in Using Critical Thinking Skills in Reading. Al-Ta Lim Journal, 24(3), 195. https://doi.org/10.15548/jt.v24i3.298

Walker, S. E. (2006). Journal writing as a teaching technique to promote reflection. Journal of Athletic Training, 41(2), 216-221. Retrieved from https://www.ncbi.nlm.nih.gov/pmc/articles/PMC1472640/

Wicaksono, V. D. (2006). Critical Thinking Skills Enhancement Through Reflective Journal of Civics 5th Graders in SDN Ngenep 5. The First International Conference on Child Friendly Education, 209-215. Retrieved from http://hdl.handle.net/11617/7215 